\title{
Research on the Türbe Complex of Suleiman the Magnificent in Szigetvár and its Fortification
}

Norbert Pap* - Máté Kitanics**

Kanunî Sultan Süleyman Türbesi, Külliyesi ve Onlara Ait Palanka Üzerine Araştırmalar

Öz — Uzmanlar Macaristan'da Zigetvar'da Kanunî Sultan Süleyman'ın türbesini 110 yıldan fazla süredir araşııırrdı. 2013 yılından önce birçok disiplin uzmanları, kendi alanının metotlarını kullanarak zayıf meslekî görüşlerini yayımlattı. Geçen yıllarda geniş multidisipliner araştırmalar başladı ve onun sonucunda eski inceleme alanları (Almás-Elmalı- deresinin kıyısı ve Turbek'teki Aziz Meryem kilisesi) reddedildi, Kanunî Sultan Süleyman'ın türbe-plankasının binaları tamamen yeni bir yerde tespit edildi. Bu makale son 110 yılın en önemli araştırma sonuçlarından bir özet sağlamakla birlikte, aynı zamanda kaynakların jeografik yorumlarını da aydınlatmak amacındadır.

Anahtar kelimeler: Osmanl, Kanunî Sultan Süleyman, türbe, Zigetvar (Szigetvár), Turbék, peyzaj onarımı, jeoarkeoloji.

\section{Introduction}

After the siege of Szigetvár, Suleiman the Magnificent (1520-1566), who conquered one third of Hungary, died early morning of 7 th of Septembre in his own tent from an unidentifiable illness. When the castle was taken, Miklós Zrínyi, baron of the Kingdom of Hungary and member of the noble Zrínyi family, was killed along with 2,300 Christian defenders of the castle. At least 20,000 Ottoman fighters were killed. This event was considered so important that Cardinal Richelieu called it a miracle, a landmark that not only saved the Habsburg house but also determined whether Europe would be under the rule of the cross or the crescent.

* University of Pécs.

** University of Pécs. 
A splendid tomb, or türbe, was ordered to be erected at the place of Suleiman's death by either Suleiman's successor, Selim II (1566-1574) or his grandson, Sultan Murad III (1574-1595). In 1576, Murad ordered two nearby villages (Becefa and Csütörtökhely) to serve as Suleiman's memorial place and commissioned the Bey of Szigetvár and the Halveti dervishes to maintain and guard the türbe. The sepulchre was surrounded by a protective palisade and heavily guarded. The site was of such key political importance that Grand Vizier of the Empire Sokullu Mehmed erected a mosque worthy of Suleiman next to the sepulchre. The building complex surrounding the mausoleum, prominent in this rural environment and of key aesthetic importance, was considered a small town at the end of the 17 th century (present-day Turbék.) No similar settlement exists, making the site a unique symbol of the spread of Islam in the region.

The türbe and the village perished during the wars of liberation led by the Habsburgs. The residential buildings in Turbék were destroyed in battles during the siege of Szigetvár (1688-1689). Although the mosque and türbe were dedicated as a church and chapel, respectively, in 1688, they too were torn down shortly thereafter. (Documentation suggests that in 1693 the War Council in Vienna discussed the disappearance of the money from the sale of the materials from the demolished buildings.) As the buildings had not survived and the use of land had changed, memories regarding the location faded over time and the Turbék of the 17th century was "lost." By the end of the 19th century, when scientific interest was revived, only legends and a few (contradictory) historical sources were available. Investigators have identified several possible locations of the türbe's original erection, but for the past century, no one has been able to identify the exact location.

Throughout the centuries, the politics of memory have served to reinterpret the location of the Sultan's death. Increased attention occasionally prompted new research and results were influenced according to the available methods of the time. An interdisciplinary approach is vital to unpacking the effects of the various legends on past research and differing narratives in order to discover the location of the türbe.

\section{International antecedents and context}

Mausoleums were typically built for members of the Ottoman elite, particularly those of the reigning family, secular leaders, and religious leaders who were 
respected as holy men. Türbes are tombs characterised by iron lattice, a baldachinroof, and closed structure. Of Persian origin, adopted by the Ottomans through the Seljuqs, ${ }^{1}$ türbes were typically built with a hemispheric, domed structure decorated with plants, geometrical shapes, and calligraphic motifs. Their base was usually hexagonal, heptagonal or octagonal, and sometimes tetragonal; however, some have even more angles and sides. Depending on available financial resources, they were decorated with marble, wall tiles, and paintings and styles evolved during the early period of the Empire in Bursa and Inznik. ${ }^{2}$ Funeral services took place in the spirit of Islam ${ }^{3}$ and in order to show reverence, Muslim burial places were typically left undisturbed; therefore, it has not been possible to explore the sultans' türbes in full. However, the exterior and interior have been studied, as well as the textiles used in them. ${ }^{4}$ The number of surviving türbes is several thousand in the territory of the former empire; Istanbul alone boasts 487 türbes. $^{5}$

After the reign of Sultan Mehmed II (1451-1481), rulers were buried in Istanbul. Only a few türbes and monuments were built outside the capital (e.g., Kosovo, Turbék). Eighteen mausoleums are known to have been built during the Ottoman occupation of Hungary, one built for Sultan Suleiman, ten for secular leaders, and seven for dervishes respected as holy men. ${ }^{6}$ Two türbes have survived to present day: the türbe of Idris Baba in Pécs and the türbe of Gül Baba in Budapest. These hexagonal, domed structures show similarities with Balkan architecture. ${ }^{7}$ When the türbe of Idris Baba was excavated, a body with its face in the direction of Mecca was discovered. ${ }^{8}$

1 Osman Turan, Selçuklular zamanında Türkiye (İstanbul: Turan Neşriyat Yurdu, 1971), p. 762.

2 Aslanapa Oktay, Türk Sanatı (İstanbul: Remzi Kitabevi, 1984), p. 454; Godfrey Goodwin, A History of Ottoman Architecture (London: Thames \& Hudson Ltd., [1971] 2003), p. 512.

3 Mehrdad Kia, Daily Life in the Ottoman Empire (Santa Barbara: The Greenwood Press Daily Life Through History Series, 2011), p. 294.

4 Özer Çalışkan, 16. Yüzyıl Osmanl Saray İ̧slemeleri (İstanbul: İSAR, 2004), p. 152.

5 Serhat Teksari, İstanbul Türbeleri (İstanbul: Gül Neşriyat, 2005), p. 340.

6 Sudár Balázs, Dzsámik és mecsetek a hódolt Magyarországon. Magyar Történelmi Emlékek. Adattárak. (Budapest: MTA BTK Történettudományi Intézet, 2014), pp. 500-504.

7 Gerő Győző, “Az oszmán-török épītészet Magyarországon (Dzsámik, türbék, fürdők)”, Müvészettörténeti Füzetek, 12 (1980), p. 180; Balázs, Dzsámik és mecsetek a hódolt Magyarországon, pp. 500-504; K. Pintér Tamás and Sudár Balázs, Oszmán-török épitészet Magyarországon (Budapest: Album, 2014), p. 75.

8 Gerő Győző, Török épitészeti emlékek Magyarországon (Budapest: Corvina kiadó, 1976), p. 60; Győző, “Az oszmán-török épītészet Magyarországon”, p. 180. 
Senyurt documented in detail the events of the repeatedly rebuilt sepulchre in Kosovo and Murad I's mausoleum. ${ }^{9}$ The memorial türbe in Kosovo was surrounded by a külliye, like the one in Turbék. It also functioned as a pilgrimage place but was not surrounded by a fortification. ${ }^{10}$ According to tradition, Murad's internal organs were buried on the battlefield too, and the mortal remains of the ruler rest in the mausoleum in Bursa, just as Suleiman's body rests in his türbe in Istanbul. ${ }^{11}$

The research in Szigetvár is interesting in that the sepulchres of the 36 Ottoman sultans in Bursa and Istanbul all survived, and only Suleiman I's tomb in Szigetvár, of all the historical monuments, perished without a trace for a long time. The fact that a pilgrimage settlement was created around the tomb is most likely related to border protection policies, the political significance of the place and the need to serve the pilgrims.

\section{Past Research on the Suleiman türbe in Szigetvar}

The first publication of scientific value in connection with Suleiman's tomb in Szigetvár is The History of Szigetvár by Béla Németh ${ }^{12}$ (1903) which has proven unreliable. According to Németh, the "marble" sepulchre was erected at the place of the sultan's tent where the church of Turbék is located today. He refers to the (erroneous) legend from Mars Hungaricus which stated that Suleiman was shot near "a linden-tree standing not far from the castle on the shore of the lake" and that his internal organs were taken from there to Turbék. Using Pál Esterházy's figure from the 1664 winter military campaign, he argues that the figure shows a fortress surrounded by a moat on three sides, enclosing the türbe and other buildings. He also mentions a "Turkish cemetery" near the Almás river and argues that the bones found there were taken and buried there; he also claims a church was erected on the site of the türbe

9 Oya Şenyurt, "Kosovada Murad Hüdavendigar Türbesi ve Ek Yapıları," METU JFA, XXIX/2 (2012), pp. 285-311.

10 Ekrem Hakkı Ayverdi, "Yugoslavya'da Türk Abideleri ve Vakıfları", Vakıflar Dergisi, 3 (1957), pp. 1-73; Semavi Eyice, "Bursada Osman ve Orhan Gazi Türbeleri”, Vakıflar Dergisi, 5 (1962), pp. 131-47; Mehmet Z. İbrahimgil ve Neval Konuk, Osmanl Mimari Eserleri, vol. I (Ankara: Türk Tarih Kurumu, 2006), pp. 438-468.

11 Şenyurt, "Kosova'da Murad Hüdavendigar Türbesi ve Ek Yapıları."

12 Németh Béla, Szigetvár története (Pécs: Pécsi Irodalmi és Könyvnyomdai Részvénytársaság, 1903), p. 389. 
in Turbék in honour of the Blessed Virgin Mary in the beginning of the 20th century.

Pál Hal also focused primarily on the period when Szigetvár was retaken and the circumstances of reoccupation and believed in the continuity of the türbechapel story. Hal is the first to confirm the identity of the "Turkish cemetery," described as an irregular pentagonal structure ${ }^{13}$ at the site marked $F$ on the map prepared in 1689 by Leandro Anguissolo. Both Németh and Hal agree that Suleiman did not die here; instead they claim that this was a cemetery of the Turks that was unearthed when the church was built and the bones reburied. It should be noted that field research to date has not found any trace of this ossuary.

In his works, Sándor Takáts ${ }^{14}$ refers to the linden tree legend, that the sultan had been buried there and that it had become a pilgrimage place for both Muslims and Christians. In his 1927 work, he emphasised that the site of the shrine church could not have been the same as that of Sultan Suleiman's türbe. ${ }^{15}$ Most scholars subscribed to Takáts beliefs, assuming that he must have known something that confirmed that the church had not been built on the site of the türbe (complex). Takáts 1915 (p. 46.) work, however, escaped the attention of researchers, which states his belief that the tomb must have been built in the immediate vicinity of the church; he argued "the church ... has never been Suleiman's tomb but it was the church of the dervishes guarding the tomb."

In his paper published in the Bulletin of Art History, József Molnár ${ }^{16}$ interpreted from Evlia Çelebi's work that the mausoleum built from "white limestone" was located at an hour's distance to the east of Szigetvár in a village where Hungarians from Szigetvár used to go for recreation and entertainment. Not knowing the views of Takáts detailed above, Molnár mistakenly presented Takáts as a predecessor who had also recognised that the türbe could not have been built in the vicinity of the church in Turbék. After studying the sketch made by Pál Esterházy during the winter campaign in 1664, Molnár suggested that the tomb must have

13 Hal Pál, Szigetvár 1688 és 1689-ben. Szigetvár török uralom alól való felszabadulásának 250. évfordulója alkalmából (Szigetvár: 1939), p. 20.

14 Sándor Takáts, "Vezīr Szokolli Musztafa Basa," Budapesti Szemle, 162 (460) (1915), pp. 41-65; Sándor Takáts, "Nagy Szolimán császár sīrja," Rajzok a török világból, IV (1927), pp. 123-132.

15 Takáts, ”Nagy Szolimán császár sīrja.”

16 József Molnár, “Szulejmán szultán sīremléke Turbéken,” Müvészettörténeti Értesito", XIV/1 (1965), pp. 64-66. 
been somewhere along the Almás stream, as the protective palisade was surrounded by a moat. In Molnár's view, the türbe must have been the pentagonal round "building" located in an enclosure, marked by $F$ on the 1689 Anguissola map, confirmed by the fact that one of the possible locations of the sultan's tent mentioned by Evlia Çelebi was on the shore of a "lake." Thus, he rejected the view that the location was the shrine church in Turbék, saying: "I find it inconceivable that the Catholic Church erected a memorial above the ashes of a 'pagan' sultan."

Nicolas Vatin ${ }^{17}$ established that there had been a fruit garden there before 1574. Based on Ottoman sources, he believed that the tomb must have been built in 1575-1576 or a few years immediately before. He argued that the türbe was needed for political reasons as a fortification in the battles fought with the Christian forces led by Captain György Zrínyi of Nagykanizsa and that the burial of the internal organs was merely a later, 17 th century legend. He believed this was the reason why contemporary authors had not mentioned the "mummification" of the Sultan's body.

Local historian of Szigetvár Imre Molnár published a hypothesis stating that the estate of the dervishes of Turbék was in Domolos, on the plain neighbouring the Turbék-Zsibót vineyard on the east. ${ }^{18}$ However, no one has been able to confirm or falsify this claim.

Many historians and Ottoman experts have contributed to our knowledge regarding Turbék and the sepulchre through their research. Klára Hegyi ${ }^{19}$ found traces of the palisaded place of worship in the cash journal. In his monograph dealing with the 18th-century history of Szigetvár, Zoltán Gőzsy ${ }^{20}$ argues that the sepulchre used to be located where the church of Turbék can be found today. Balázs Sudár ${ }^{21}$ summarizes the most important Ottoman sources and data related to the location in a databank. He points out several inconsistencies regarding the location of the türbe, which are yet to be resolved. He claims that "local tradi-

17 Nicolas Vatin, "Un türbe sans maître. Note sur la fondation de la destination du türbe de Soliman-le-Magnifique à Szigetvár”, Turcica, XXXVII (2005), pp. 9-42.

18 Imre Molnár, Molnár Imre válogatott īrásai (Szigetvár: Szigetvári Várbaráti Kör, 2009), p. 207.

19 Hegyi Klára, A török hódoltság várai és várkatonasága, I-III (Budapest: MTA Történettudományi Intézete, 2007), p. 1631.

20 Gözsy Zoltán, Szigetvár története a 18. században (Szigetvár: Szigetvári Kultúr- és Zöld Zóna Egyesület és a Szigetvári Várbaráti Kör, 2012), p. 324.

21 Balázs, Dzsámik és mecsetek a hódolt Magyarországon, pp. 500-504. 
tions associated it with the church on the Turbék Hill, but no trace of it was found during the excavations carried out here."

The archaeologist Valéria Kováts identified the "Turkish cemetery" as the site of the headquarters and place where Suleiman had died and believed the tomb structure marked the church in Turbék rather than with the "Turkish cemetery." In 1971, she carried out excavations inside the church and in the churchyard and made her excavation documentation public. ${ }^{22}$ According to her hypothesis, there might have been a Gothic Chapel at this place in the Middle Ages, which the Ottomans might have used for building the türbe. She also identified and described several building materials and fittings added at a later date to the church. However, she failed to identify any traces of the former mausoleum, the Turkish fortification, the basic walls, moats or people who had settled there, nor its Gothic antecedent. After examining the demolition waste allegedly found in the churchyard, which she believed originated from the age of the Turkish occupation, she concluded that the sepulchre and the fortress surrounding it must have stood where the church is located today. In 1971 and 1972, she carried out excavations about one kilometer from the church on the top of the Turbék-Zsibót vineyards. ${ }^{23}$ During these excavations she identified a "public building" originating from the period of the Turkish occupation that was built with a quadratic floor plan using carved stones. She only explored a certain segment of the building and never finished the investigations and as the documentation of the excavations can no longer be found in the museum archive, unfortunately, there is no detailed information about her research except for a few contemporary photos.

Because of limited excavation documentation prepared by Kováts, and given that she was not yet able to rely on geophysical examinations, Erika Hancz and Fatih Elçil carried out probing excavations in the church garden and to the south in 2009, which were preceded by geophysical examinations in the interior of the church and in the church garden. ${ }^{24}$ On the basis of these examinations, they established that the church in Turbék could not have been the place where the sultan's tomb was built. Not only did they fail to find any trace of large build-

22 Kováts Valéria, Turbék ásatási jelentés (Pécs: Janus Pannonius Múzeum Régészeti Adattár, 1971).

23 Kováts Valéria, “Szigetvár-Turbék szőlőhegy”, Régészeti füzetek I., No. 26. (1973), p. 113.

24 Erika Hancz and Fatih Elçil, "Excavations and Field Research in Sigetvar in 2009-2011, Focusing on Ottoman-Turkish Remains", International Review of Turkish Studies, II/4 (2012), pp. 74-96. 
ings, fortifications, a palisade or a moat, which had been mentioned in numerous sources, but they did not uncover any archaeological finds that would show signs of the everyday life of people who might have settled there permanently. The objects identified there originated from the 18th-century or later. Due to financial limitations, however, they did not examine the entire surface, so they were not able to clarify the origin of the demolition bricks allegedly found by Kováts in the churchyard, which she believed to be of Turkish origin.

In sum, research conducted between 1903 and 2012 was unable to provide an unambiguous answer as to the whereabouts of the türbe and sultan's tomb and what role the Helping Blessed Virgin Mary church in Turbék might have had in preserving the memory of the site. Several unverifiable hypotheses were raised, as the available archival sources were scarce and did not offer unambiguous interpretation (e.g., whether the site was on the shore of the lake or up on the hills). No archaeological finds were uncovered at the excavation sites, so researchers have been unable to clearly identify the location of the türbe and the buildings surrounding it. Interpreting the environmental features of 16th- and 17th-century sources in the 20th- and 21st-century landscape posed a major challenge. The information made available to the experts of each discipline was much too limited and uncovered unrelated and seemingly random ideas and insights. These problems made it necessary to review the data, explore new historical sources and use new methods and technologies. Thus, a new multidisciplinary research team was set up through a support agreement signed in Ankara in autumn, 2012.

\section{Research findings of the multidisciplinary team}

The latest research concept, designed by Norbert Pap, ${ }^{25}$ is based on a geographical approach and multidisciplinary teamwork, focusing on collecting additional information, reconsidering the framework of the research, sharing methods from across the natural sciences, strengthening the multidisciplinary nature of the research, enforcing an integrated approach based on the landscape, and using consistent and strict quality assurance procedure. The team leader aimed to

25 Norbert Pap, “A szigetvári Szülejmán-kutatás kezdetei, a 2013-as év fontosabb eredményei I Sigetvar'da Kanuni Sultan Süleyman Hakkında Yapılan Araştırmaların Ana Noktaları ve 2013 Yılı Sonuçları," Szülejmán szultán emlékezete Szigetváron/Kanuni Sultan Süleyman'in Sigetvar'daki hatırası, ed. Norbert Pap [= Mediterrán és Balkán Fórum, VIII (2014)], pp. 23-36. 
ensure that the insufficient and accidental information is systematically analysed and the range of the data to be examined is considerably extended.

\section{Reinterpretation from a geographical aspect}

This new approach attached more importance to archival sources starting from the end of the 17th century and those sources based on maps. The number of documents stemming from this period is quite large and can be used effectively for localisation as their data content is richer and more precise from a geographical aspect (e.g., litigation documents, urbariums/register of fief ownership, old maps/drawings, military surveys, cadastral maps).

The Little Ice Age overlapped with the period from the middle of the 16thcentury up to the middle of the 18th-century which meant that the climatic conditions reflected in contemporary documents must have been very different from what they are like today. Starting from this point, we were able to get a picture of the 16-17th-century environmental conditions. The explorations were supported by the Turkish government largely through TIKA as part of a grant agreement signed in November 2012 in Ankara and launched in January 2013. In addition to geographers, experts included historians, art historians, archaeologists, geomorphology experts, information technology specialists, geophysicists and even pathologist. The composition of the research group and consultants changed from time to time. The research was documented with due care by observing the general rules of the profession on the basis of the requirements specified in the agreements.

In order to better understand the written sources and support the archaeological investigations, Péter Gyenizse and Zita Bognár carried out an examination based on a geographic information system (GIS) which helped reconstruct the contemporary (16th-17th-century) water network, road network, and land use. ${ }^{26}$ Using this model, the team not only narrowed down the research area, but landscape elements were uncovered which had appeared in the sources. Data regarding the water network was of particular importance and prompted the

26 Péter Gyenizse and Zita Bognár, "Szigetvár és környéke 16-17. századi tájrekonstrukciója katográfiai és geoinformatikai módszerekkel/Sigetvar ve Çevresinin Haritacılık ve Jeoenformasyon Yöntemleriyle 16-17. Yüzyıl Peyzaj Rekonstrüksiyonu," Szülejmán szultán emlékezete Szigetváron/Kanuni Sultan Süleyman'in Sigetvar'daki hatırası, ed. Norbert Pap [= Mediterrán és Balkán Fórum, VIII (2014)], pp. 73-90. 
revision of several earlier hypotheses. It turned out that one of the hypothetical locations of the türbe, the area along the Almás stream, was periodically underwater at the time, so it was unsuitable for building anything or settling down permanently. As it was not possible to see the castle from the neighbourhood of the church in Turbék located on soggy land, it was obviously unsuitable as a command point. This enabled us to make considerable progress in identifying the possible and the unlikely command points. Erika Hancz examined a wider range of Ottoman sources. ${ }^{27}$ Máté Kitanics ${ }^{28}$ identified and analysed a wide range of Christian sources published in Hungarian, German, and Latin that eventually turned out to be conclusive for the identification of the sultan's tomb. Previously known sources were thoroughly reviewed and entirely new sources enabled us to obtain a large number of data of a geographical nature assisting localisation (Table 1).

\begin{tabular}{|c|c|c|c|c|c|}
\hline & $\begin{array}{c}\text { Source of infor- } \\
\text { mation }\end{array}$ & $\begin{array}{c}\text { Distance/time } \\
\text { from the castle } \\
\text { and Szigetvár }\end{array}$ & $\begin{array}{c}\text { Geographical } \\
\text { nature of the } \\
\text { location }\end{array}$ & Land use & $\begin{array}{c}\text { Degree of devel- } \\
\text { opment }\end{array}$ \\
\hline 1. & $\begin{array}{c}\text { Ferenc Cserenkó } \\
(1566)\end{array}$ & $\begin{array}{c}\text { half a mile } \\
\text { (about } 4 \mathrm{~km}) \\
\text { from the castle }\end{array}$ & $\begin{array}{c}\text { Szemlő Hill ("up } \\
\text { on the hill”) }\end{array}$ & no data & no data \\
\hline 2. & $\begin{array}{c}\text { Sámuel Budina } \\
(1566 / 1568)\end{array}$ & $\begin{array}{c}\text { half a mile } \\
\text { (about } 4 \mathrm{~km}) \\
\text { from the castle }\end{array}$ & Szemlöhegy & $\begin{array}{c}\text { near the vi- } \\
\text { neyards }\end{array}$ & no data \\
\hline 3. & $\begin{array}{c}\text { Ottoman source } \\
(1573)\end{array}$ & no data & no data & fruit garden & not developed yet \\
\hline
\end{tabular}

27 Erika Hancz, "Nagy Szülejmán Szultán Szigetvár környéki sátorhelye, halála és sīremléke az oszmán ỉrott forrásokban/Osmanlı Kaynaklarına Göre Kanuni Sultan Süleyman'ın Sigetvar'daki Otağ Yeri, Ölümü ve Türbesi,” Szülejmán szultán emlékezete Szigetváron/Kanuni Sultan Süleyman'in Sigetvar'daki hatırası, ed. Norbert Pap [= Mediterrán és Balkán Fórum, VIII (2014)], pp. 55-71.

28 Máté Kitanics, "Szigetvár-Turbék: A szultán temetkezési helye a 17-18. századi magyar, német és latin források tükrében/Sigetvar-Turbék: 17-18. Yüzyıllarına Ait Macarca, Almanca ve Latince Kaynaklar Temelinde Kanuni Sultan Süleyman'ın Mezarının Oluşturulduğu Bölge," Szülejmán szultán emlékezete Szigetváron/Kanuni Sultan Süleymanin Sigetvar'daki hatırası, ed. Norbert Pap [= Mediterrán és Balkán Fórum, VIII (2014)], pp. 91-109.

29 Lajos Ruzsás and Endre Angyal, "Cserenkó és Budina," Századok, CV (1971), pp. 69-57.

30 Imre Molnár, Budina Sámuel históriája, magyarul és latinul Szigetvár 1566. évi ostromáról (Szigetvár: A Szigetvári Várbaráti Kör Kiadványai 6, 1978), p. 45.

31 Nicolas Vatin, "Un türbe sans maître. Note sur la fondation de la destination du türbe de Soliman-le-Magnifique à Szigetvár”, Turcica, XXXVII (2005), pp. 42-9. 


\begin{tabular}{|c|c|c|c|c|c|}
\hline & $\begin{array}{l}\text { Source of infor- } \\
\text { mation }\end{array}$ & $\begin{array}{l}\text { Distance/time } \\
\text { from the castle } \\
\text { and Szigetvár }\end{array}$ & $\begin{array}{l}\text { Geographical } \\
\text { nature of the } \\
\text { location }\end{array}$ & Land use & $\begin{array}{l}\text { Degree of devel- } \\
\text { opment }\end{array}$ \\
\hline 4. & $\begin{array}{l}\text { Ottoman register }^{32} \\
(1574)\end{array}$ & no data & no data & no data & $\begin{array}{l}\text { the mosque where } \\
\text { Suleiman's body } \\
\text { was temporarily } \\
\text { buried }\end{array}$ \\
\hline 5. & $\begin{array}{l}\text { Ottoman register } \\
\text { (1579) of Szigetvár } \\
\text { and its neighbour- } \\
\text { hood }^{33}\end{array}$ & "near Szigetvár" & $\begin{array}{l}\text { a room in Khan } \\
\text { Suleiman's clois- } \\
\text { ter (kasaba) }\end{array}$ & $\begin{array}{l}1 \text { vineyard, } 1 \\
\text { plot of arable } \\
\text { land }\end{array}$ & $\begin{array}{l}\text { two mahalle-sized } \\
\text { communities with } \\
23 \text { and } 28 \text { house- } \\
\text { holds, respectively }\end{array}$ \\
\hline 6. & $\begin{array}{l}\text { Evlia Çelebi }{ }^{34} \\
\quad(1664)\end{array}$ & $\begin{array}{l}\text { one hour's } \\
\text { distance from } \\
\text { the castle to the } \\
\text { east }\end{array}$ & $\begin{array}{c}\text { on top of a large } \\
\text { mountain }\end{array}$ & $\begin{array}{c}\text { at a place } \\
\text { among hills and } \\
\text { gardens }\end{array}$ & $\begin{array}{l}\text { the tomb repro- } \\
\text { ducing the size of } \\
\text { Khan Suleiman's } \\
\text { tent }\end{array}$ \\
\hline 7. & $\begin{array}{c}\text { J. Ch. Wagner }{ }^{35} \\
(1689)\end{array}$ & $\begin{array}{c}\text { a two-hour } \\
\text { distance outside } \\
\text { the island }\end{array}$ & $\begin{array}{c}\text { on a hill (Türbe } \\
\text { Daghi) }\end{array}$ & $\begin{array}{l}\text { vineyards and } \\
\text { fruit gardens }\end{array}$ & Fortress \\
\hline 8. & $\begin{array}{c}\text { Urbaria et } \\
\text { Conscriptiones }^{36} \\
(1692)\end{array}$ & $\begin{array}{l}\text { an hour from } \\
\text { the town }\end{array}$ & $\begin{array}{l}\text { vineyard (Tur- } \\
\text { bék) }\end{array}$ & $\begin{array}{l}\text { vineyards and } \\
\text { fruit gardens }\end{array}$ & $\begin{array}{l}\text { a deserted Turkish } \\
\text { mosque where } \\
\text { Suleiman used to } \\
\text { be buried }\end{array}$ \\
\hline 9. & $\begin{array}{c}\text { Urbaria et } \\
\text { Conscriptiones }^{37} \\
(1692)\end{array}$ & $\begin{array}{l}\text { half a mile } \\
\text { (about } 4 \mathrm{~km} \text { ) }\end{array}$ & $\begin{array}{l}\text { the village of } \\
\text { Turbék on a hill }\end{array}$ & $\begin{array}{c}\text { fruit gardens, } \\
\text { vineyards and } \\
\text { arable land }\end{array}$ & $\begin{array}{c}\text { stone-walled } \\
\text { church with a tall } \\
\text { tower }\end{array}$ \\
\hline 10 & $\begin{array}{c}\text { Hoffinanz Ungarn } \\
\text { (1693) }\end{array}$ & no data & Turbék & no data & $\begin{array}{l}\text { "chapels" made } \\
\text { from marble with } \\
\text { lead roof, a tower } \\
\text { where Suleiman's } \\
\text { tomb use to be }\end{array}$ \\
\hline
\end{tabular}

32 Sinan Bey oğlu eski Sadrazam Şehit Mehmet Paşa Vakfi, 1574.

33 Előd Vass, "Szigetvár város és a szigetvári szandzsák jelentősége az Oszmán-Török Birodalomban 1565-1689," Tanulmányok a török hódoltság és a felszabaditó háborúk történetéből (1993), pp. 217-193.

34 Evliyâ Çelebi b. Derviş Mehemmed Zıllī, Evliyâ Çelebi Seyahatnâmesi: Topkapı Sarayı Kütüphanesi Bağdat 308 Numaralı Yazmanın Transkripsiyonu-Dizini, vol. VII, eds. Yücel Dağl1, Seyit Ali Kahraman, Robert Dankoff (İstanbul: Yapı Kredi Yayınları, 2003), pp. 1819.

35 Johann Christoph Wagner, Wagners Christlich-und Türckischer Städt- und Geschicht-Spiegel... Anhang/Oder Continuation Zu dem Christlich-und Türckischen Staedt ... (Augsburg: Gedruckt und Verlegt bey Jakob Koppmayer 1700), p. 100.

36 National Archives of Hungary, Urbaria et Conscriptiones, $8,57: 50$.

37 National Archives of Hungary, Urbaria et Conscriptiones, 30 :136, 3.

38 National Archives of Hungary, Hoffinanz Ungarn, W2279. 


\begin{tabular}{|c|c|c|c|c|c|}
\hline & $\begin{array}{l}\text { Source of infor- } \\
\text { mation }\end{array}$ & $\begin{array}{l}\text { Distance/time } \\
\text { from the castle } \\
\text { and Szigetvár }\end{array}$ & $\begin{array}{l}\text { Geographical } \\
\text { nature of the } \\
\text { location }\end{array}$ & Land use & $\begin{array}{c}\text { Degree of devel- } \\
\text { opment }\end{array}$ \\
\hline 11. & $\begin{array}{c}\text { Urbaria et } \\
\text { Conscriptiones }^{39} \\
(1720)\end{array}$ & no data & $\begin{array}{l}\text { vinyard, Turbék, } \\
\text { which used to } \\
\text { be called Sibod } \\
\text { (Zsibót) }\end{array}$ & vineyard & $\begin{array}{l}\text { there used to be } \\
\text { tomb-shaped } \\
\text { mosque here }\end{array}$ \\
\hline 12. & $\begin{array}{c}\text { Prothocollum }^{40} \\
(1717-1734)\end{array}$ & no data & $\begin{array}{l}\text { "Turkish fortifi- } \\
\text { cation" }\end{array}$ & $\begin{array}{l}\text { arable land } \\
\text { (maize), un- } \\
\text { cultivated land } \\
\text { where the } \\
\text { fortress used to } \\
\text { be located }\end{array}$ & $\begin{array}{c}\text { there used to be } \\
\text { "Turkish walls" here, } \\
\text { as well as a fortress } \\
\text { and a demolished } \\
\text { well }\end{array}$ \\
\hline 13. & $\begin{array}{l}\text { Prothocollum }{ }^{41} \\
\text { (1738) }\end{array}$ & no data & $\begin{array}{l}\text { "Turkish fortifi- } \\
\text { cation" }\end{array}$ & $\begin{array}{l}\text { arable land } \\
\text { (maize) }\end{array}$ & $\begin{array}{l}\text { there used to be } \\
\text { a tekke (dervish } \\
\text { monastery) and a } \\
\text { fortification here }\end{array}$ \\
\hline 14. & $\begin{array}{c}\text { Urbaria et } \\
\text { Conscriptiones }^{42} \\
(1747)\end{array}$ & no data & $\begin{array}{l}\text { "Turkish fortifi- } \\
\text { cation" }\end{array}$ & arable land & no data \\
\hline 15. & Visitatio $^{43}(1756)$ & no data & $\begin{array}{l}\text { vinyard hill, "old } \\
\text { Turkish palisade" }\end{array}$ & vineyards & $\begin{array}{l}\text { ruined Turkish } \\
\text { mosque }\end{array}$ \\
\hline 16. & Contractus $^{44}$ (1789) & no data & $\begin{array}{l}\text { "Turkish fortifi- } \\
\text { cation" }\end{array}$ & arable land & no data \\
\hline
\end{tabular}

Table 1: Written sources and notes for the Sultan's tomb (the türbe, the Turkish fortification, Turbék and the place where he died) that assist geographical localisation

The sources listed above pointed to a location approximately 4-4.5 kilometres north or northeast from the castle of Szigetvár on the top of the large hill. Based on this, in February and March 2013 we identified the location as being 4.2 kilometres from the castle in the neighbourhood of the Szilvás tavern on the top of the vineyard. ${ }^{45}$

39 National Archives of Hungary, Urbaria et Conscriptiones, 66: 21, 1.

40 Szigetvár Presbytery, Prothocollum Parochia Magno Szigethana (1717-1734) No.1774.

41 Szigetvár Presbytery, Prothocollum Parochia Magno Szigethana (1738) No.1774.

42 National Archives of Hungary, Urbaria et Conscriptiones, 94: 5 ,30.

43 Zoltán Gözsy, Baranya és tolna vármegye plébániáinak összeirása 1753-1757 (Pécs: Seria

Historicae Dioecesis Quinqueecclesiensis XIV., 2016), p. 409.

44 Somogy County Archives, Szigetvár Község Levéltára, Contractusok, 1789 (1604-1891).

45 Norbert Pap and others, "Finding the tomb of Suleiman the Magnificent in Szigetvár,

Hungary: historical, geophysical and archeological investigations," Die Erde, CXLVI/4 (2015), pp. 289-303. 
This area was not entirely unknown, as it had already been identified and "documented" as an "Ottoman public building" 46 and "Turkish ruin" which had been reported by residents as an archaeological site. However, its exact size, internal structure, nature and function remained unknown. The debate which emerged later, initiated by Géza Szabó, ${ }^{47}$ as to who should be given credit for identifying the location, is perhaps of little value since it is an Ottoman archaeological find that has been known since at least 1971. Nevertheless, the question whether this site might be associated with the sultan's burial place was raised by Kitanics and is indisputable on the basis of detailed research documentation.

\section{3 field investigations}

Extensive field investigations began in 2013 and were documented in reports prepared by archaeologist Erika Hancz on the basis of the permit she was issued. It is important to note here that these investigations were not carried out by individual researchers but collectively by the members of the research group. The field research results are problematic: they were insufficient, unsuitable for publication, and the interpretation of the data was rather contradictory. The first archaeological observations and geodesic and geophysical investigations proved to be a dead end in several cases, and the hypotheses were not verified conclusively. The measurements made during this period in the neighbourhood of the church (in order to identify the location of the türbe and its environment) and the probing excavations carried out 750 meters north of the church (in order to confirm the presence of mass graves of the Ottoman army) proved to be unsuccessful. Doubts concerning the methodology of data collection arose and interpretation of the data collected in the excavations carried out north-west of the church (in regards to the shallow, silted ditch running in the east-west direction) is highly questionable due to insufficient data. Nothing confirmed Szabós view that this might have been the northern trench of the Ottoman camp. ${ }^{48}$ The re-

46 Kováts, “Szigetvár-Turbék szőlőhegy,” p. 113.

47 Géza Szabó, "Leletanyag intenzitásvizsgálatok a Szülejmán szultán szigetvári türbéjéhez tartozó kaszaba helyének meghatározásához," Archeometriai Mühely, XII/2 (2015), pp. 89102.

48 Géza Szabó and others, "A Szülejmán-kori harcászat és haditechnika a szigetvári ágyú és lövedékek archeometallurgiai vizsgálatának tükrében,” Gesta, XII (2013), pp. 83-115; Erika Hancz, Szigetvár külterület, Kápolna melletti dülo", kutatóárkos régészeti feltárása, ásatási jelentés (Pécs: Pécsi Tudományegyetem, 2013/2015), p. 7. 
search group believes that it might have been a drainage ditch made after the period of the occupation, and that it could not have been used for defence purposes as it was quite shallow. The geophysical examinations carried out at the top of the vineyards did not heed any definite results. The research team worked under difficult conditions (e.g., metal wires laid about extensively) and the equipment used by the geophysicist in the 2013 investigations was quite limited. Therefore, the team was unable to obtain valuable data and made no progress.

The additional field examinations carried out in summer of 2013 in order to identify the size and the structure of the site in the vineyards were also unsuccessful in several aspects. The examination of the findings collected on the surface was selective as the area was highly developed; most of the land was in use (i.e., grassy fields) and fenced off and many owners refused to agree to measurement. As a result, we were able to carry out examinations that were credible only in part and were, as a whole, rather distorted. Later Szabó published the common research findings without proper authorisation from either the project leader nor the leader of the excavations ${ }^{49}$ and the content of these publications included several mistakes and errors. Among other issues, he determined the course of the ditch running along the vineyard location not by measurement but by estimation, and this later proved to be a significant mistake. When his contract expired, the research group discontinued cooperation with Szabó.

\section{Repetition of field research using advanced tools}

After Szabó left, significant changes were made in the research project. Both the methodology and the staff were reorganized. The research group repeated all the investigations in the field using different methods, employing a GPS tool (Garmin GPSMAP 60CSx Handheld GPS Navigator) and drone. These tools enabled more thorough exploration of the site and the team successfully determined the site's size and the route of the ditch by means of micro-relief modelling with the use of air photos in January and February 2015.

49 Szabó and others, “A Szülejmán-kori harcászat és haditechnika a szigetvári ágyú és lövedékek archeometallurgiai vizsgálatának tükrében,” pp. 83-115.; Géza Szabó and others, "Szülejmán szultán szigetvári türbéje körül talált izniki fajansztöredékek összehasonlītó vizsgálata és az ahhoz kapcsolódó terepi kutatások eredményei," Gesta, XIII (2014), pp. 59-78; Szabó, "Leletanyag intenzitásvizsgálatok a Szülejmán szultán szigetvári türbéjéhez tartozó kaszaba helyének meghatározásához,” pp. 89-102. 
In October 2014, the team began combining several methods to collect a series of geophysical measurements at the vineyard site and in the immediate and broader environment of the church in Turbék, working closely with geophysicists of Geomega Kft (Tamás Tóth and Zoltán Hámori). The team carried out the examinations using a ground conductivity meter (EM-38) and a vertical magnetic MagMapper (G-858) as well as a soil radar. A Turkish expert, a geophysicist, and an archaeologist assisted the team in carrying out the measurements as consultants and as a result of this close collaboration, the examinations provided useful data at both sites. ${ }^{50}$

The ground penetrating radar (GPR) enabled identification of three buildings in the centre which correlated with the results of the field research that we had repeated. One was a square building oriented towards Mecca, likely the same building as the one partially explored by Valéria Kováts in 1972 and identified as an Ottoman public building; this building was also dubbed the "Turkish ruin" or solitary watchtower in literature and general knowledge. Before the archaeological explorations, the research team assumed it must have been a mosque. The second building was found northwest of the first and was larger and consisted of cells; it also oriented to the southeast and had been assumed by the team to have been the dervish monastery. In addition to the ruins of a third building, the function of which was still unclear at the time, traces of additional buildings were found farther away from the centre of the village, mainly extended to the south. These buildings, however, must have been smaller and made from less durable materials than those in the centre of the village. From September 2015, research work continued in cooperation with the Research Centre for the Humanities, the Hungarian Academy of Sciences under the joint leadership of Norbert Pap and Pál Fodor.

First, the smallest element of the three-building complex was explored under the direction of archaeologist Erika Hancz in the autumn of 2015. The exploration uncovered a square-planed building covered with stone tiles that could be accessed through a three-sided entrance hall. Its central room was $7.8 \times 7.8$ metres and there was no trace of a mihrab or a minaret. There was a 2 meter deep robber pit with a diameter of 2 metres in the centre of the main room of the 1-1.5 metre thick stone and Turkish brick building, the same place where Pál Esterházy’s 1664 sketch marks the site of Suleiman's tomb. In all likelihood, this

50 Tamás Tóth and Zoltán Hámori, Research in Szigetvár localising the former Ottoman settlement of Turbek, the place where the inner organs of Suleiman the Magnificient were buried (Budapest: Report of geophysical examinations in Turbék made by Geomega LTD, 2014), p. 38. 
pit was dug by looters at the end of the 17 th century searching for the legendary "golden box" that was believed to contain Suleiman's internal organs. The building blocks that had luckily survived and had been uncovered seemed to be related to the ornaments in Sultan Suleiman's mausoleum in Istanbul. By the end of the excavations, there were clear signs that this building, which had been identified as an imperial edifice by both Hungarian and Turkish scholars, could be nothing more than Suleiman's tomb.

After initial explorations of the first building, an additional geophysical survey carried out in the winter of $2015^{51}$ further confirmed the traces of a building with a floorplan similar to but a bit larger than that of the mausoleum, suggesting the foundation of a minaret, marking this building as a mosque. Next to the presumed mosque, the aforementioned building with cells was confirmed to be the dervish monastery identified in 2014.

The mosque and the northern wing of the U-shaped dervish monastery was finally explored in May and June 2016. The excavations continued in August 2017 to explore sections of the western and southern wings of the monastery. The almost 5-metre wide and more than 2.6-metre deep protective ditch surrounding the türbe complex and the palisaded fortress was also identified and cross-sectioned. According to the examinations, the palisade wall had been linked to its inner, southern side and had been renewed several times. The examinations of the history of the ditch were lead by Pál Sümegi. In June 2016, field samples were taken and the laboratory analyses were carried out in the summer of 2017 which helped us draw conclusions regarding the composition of the flora and fauna at the end of Turkish rule, providing numerous data on the reconstruction of the environment. These findings resulted in the most important discoveries for providing a clear picture of environmental history in the Ottoman age; the findings also provided a good basis for comparison of the replenishment of objects located at Ottoman castles (Pápa, Szentgotthárd) which were studied using the same methodology. Everything indicates that the settlers introduced a unique oriental plant culture in Turbék.

During the site inspections in 2014 and excavations in 2015-2017, 16-17thcentury ceramics, porcelain and earthenware fragments, stove tiles, Christian and Turkish silver coins, jewellery, various articles for personal use, lead roofing felt pieces, as well as bullets, rifle bullets and cannonballs were uncovered.

51 Ecthelion Bt., Jelentés a 2015. december 1-3. között Szigetvár-Zsibót területén végzett talajradaros felmérésröl (Pécs: 2015), p. 3. 
The 2014 archival research established that the church was built later (in 1705 and later in several stages) than the time when the türbe was destroyed (1692). The "Turkish fortification" was mentioned in the sources on several occasions at a place farther away from the church. In order to finally exclude the Turkish antecedent, we carried out empirical investigations at the site. The geophysical investigations carried out in the church garden and its vicinity (on both sides of the road to Turbék) and those at the vineyard did not uncover any anomaly that would have suggested the existence of large buildings, a protective ditch or the remains of a palisade. ${ }^{52}$ Only two smaller anomalies ( $2 \times 3$ and $3 \times 3$ metres) were found: depressions in the south-western corner of the churchyard and the area around the plinth in front of the church, indicating human intervention from the 18th century or later. A specialist examined the structure of the bricks in the wall of the church identified by Szabó as Turkish brick, ${ }^{53}$ however the expert found it was not from the Ottoman period.

Between July and November 2016, Kitanics examined the 0.38 hectare garden of the church in Turbék with a Teknetics Eurotek metal detector. In order to achieve as detailed and accurate results as possible, the survey was conducted in several stages, ensuring that each section of the garden was fully examined at least three times. Altogether 314 coins were found in the churchyard. Based on the year of minting, in line with previous geophysical surveys and archaeological explorations $(1971,2009)$, it was confirmed that the churchyard was put to use only at the beginning of the 18 th century. The two oldest coins found there a 3-penny silver coin from 1720 and a 1-penny silver coin from 1721.

\section{Conclusion}

This paper presented arguments, ideas and evidence regarding the major sites near Szigetvár identified in previous research (i.e., Almás stream, Turbék church) and a new site proposed in the 2013 research, the Turbék-Zsibót vineyard location. In addition to examining the newly explored written sources and map-like drawings, the members of the research group reinterpreted the previously explored sources and selected information suitable for geographical identification. The results point to a hilly area 4.2 kilometres northeast of the castle.

52 Tóth and Hámori, Research in Szigetvár localising the former Ottoman settlement of Turbek, p. 38.

53 Szabó and others, "Szülejmán szultán szigetvári türbéje körül talált izniki fajansztöredékek összehasonlitó vizsgálata és az ahhoz kapcsolódó terepi kutatások eredményei,” pp. 59-78. 
By collecting surface finds, examining their frequency and carrying out geophysical examinations, an Ottoman settlement was identified at the TurbékZsibót vineyard location called Turbék. Archaeological explorations conducted from 2015-2016 determined the function of the three central buildings which face Mecca in a northwest-southeast direction in the following order: the dervish monastery (tekke), the mosque and the sultan's türbe. In addition, 2014-2016 investigations proved that it was impossible that the Helping Blessed Virgin Mary church was built upon the türbe and also established that there were no large Ottoman buildings and fortifications in the vicinity of the church; the site was used only from the beginning of the 18th century.

Research before 2013 was characterised by narrowly focused studies of single researchers. These studies relied heavily on the unproven claims of sources as far back as 1566. As such, key words used by these researchers were place of tent, place of death, waterside place, türbe-church continuity and folk tradition. Because the battlefield was not investigated thoroughly and assumptions were not strongly evidence-based, researchers' claims were based on an unproven location of the siege camp and were quite speculative in several cases. (For example, one source claimed that the siege required a certain degree of closeness to a particular castle calculated from the sultan's camp or tent and that this distance could not have been more than 2 to 3 kilometres.) On the basis of the landscape reconstruction examination, it was paramount that the assumptions regarding the possible location of the siege camp be reconsidered. The size of the dry area around the castle also suggested that the Ottoman army might have set up its camp at a larger distance from the castle than previously assumed.

Due to the passing of time and shortage of data in the sources, we are unable to reconstruct every place (e.g., place of death, tent, and türbe) and every possible situation mentioned in previous research. It is not entirely clear where the sultan's camp was set up during the siege but certain sources lead us to believe that he had a camp in at least two different locations: a waterside camp and the other where the türbe was later erected. Folk tradition and later sources did refer to these sites but also contradict each other. For example, some 1566 sources locate the sultan's camp "on the hill," but according to folk legends the sultan's tent was located in the vineyard. It is possible that the place of Suleiman's death marked $F$ on the 1689 Anguissola drawing might also reflect the "waterside camp" that has been held in the memory of several generations. Further evidence is indicated by the moat in the portrayal of Turbék in 1664; as a 
moat needs water, in the 20th century view, it must have been taken from the Almás stream.

Another problem was, and still is, the politics of memory regarding the site. Many claims and acts regarding the place of the sultan's death are based on the values of the key actors of the time which shaped the cultural historical map as well. For example, on several occasions commemorative texts were displayed and monuments set up on the anniversaries of the siege (1566) and the reoccupation (1689). This is how the memorial plate for the sultan's sepulchre, written in Ottoman-Turkish and Hungarian and placed on the wall of the Helping Blessed Virgin Mary church in 1913, became evidence for the location. In addition, large statues were erected in the Hungarian-Turkish Friendship Park at the alleged site of Suleiman's death on the 500th anniversary of the sultan's birth in 1994; a symbolic grave and sepulchre (türbe) of the ruler were also built. For the Turks, the park designated the place of the sultan's tomb on the bank of the Almás stream. For others, evidence was represented by the Turkish inscription written in Arabic letters on the wall of the church in Turbék. Therefore, researchers who did not know the local geographical conditions in comparison to the strong symbolic messages and folklore might have been misled. Precise scientific investigations were sometimes disturbed and occasionally limited by religious and political considerations and their consequences. Source criticism and repeated verification is vital to uncovering evidence-based facts.

Suleiman's tomb not only generates a mystic or scientific interest but also arouses the attention of those interested in "treasures". Evlia Çelebi (1664) noted that the internal organs of the sultan were buried in a golden vessel. The attention devoted to the grave was probably influenced by the ambition to make a profit. In the meantime, the "treasure" has become immaterial for some people, while the place itself has come to represent financial value. Today's treasure hunters, those longing for media attention as well as those hunting for a reward, bombard researchers, the Hungarian and the Turkish governments and the local municipality with fantastic or less fantastic ideas.

In March 2018, the attention of those interested in treasure and research was raised again by an unprecedented map representation made by Leandro Anguissola, offered for sale at a Cologne auction. The architect represented not only the siege of Szigetvár but also Turbék as the site where Suleiman's internal organs were buried. This map from 1689 shows Turbék at the same place, in the vineyard, where our research team identified it. 


\begin{abstract}
Researchers have been searching for the türbe (tomb) of Suleiman the Magnificent in Szigetvár, Hungary for over 110 years. Although scholars from a variety of disciplines have published numerous works on the subject, their methodologies have been limited to those established before 2013. In the last several years, newer multidisciplinary examinations have been conducted and as a result, the former examination sites (i.e., locations along the Almás stream and the Blessed Virgin Mary church in Turbék) were abandoned and a new location identified. This paper gives an overview of the principal findings over the last 110 years, highlighting contradictions and interpreting the geographical descriptions of these sources.
\end{abstract}

Keywords: Ottoman, Suleiman the Magnificent, türbe, Szigetvár, Turbék, landscape reconstruction, geoarchaeology.

\title{
Bibliography
}

National Archives of Hungary, Hoffinanz Ungarn, W2279

National Archives of Hungary, Urbaria et Conscriptiones, $136: 30,3$.

National Archives of Hungary, Urbaria et Conscriptiones, $50: 57,8$.

National Archives of Hungary, Urbaria et Conscriptiones, $66: 21,1$.

National Archives of Hungary, Urbaria et Conscriptiones, 94 : 30, 5.

Somogy County Archives, Szigetvár Község Levéltára, Contractusok, 1789 (1604-1891)

Szigetvár Presbytery, Prothocollum Parochia Magno Szigethana (1717-1734) No.1774

Szigetvár Presbytery, Prothocollum Parochia Magno Szigethana (1738) No.1774

Ágoston, Gábor: "Muszlim hitélet és művelődés a Dunántúlon a 16-17. században," Tanulmányok a török hódoltság és a felszabaditó háborúk történetéböl. A szigetvári történész konferencia elöadásai a város és vár felszabaditásának 300. évfordulóján (1993), pp. 277-292.

Angelicus, P.: "Regnum Marianum,” Religio, XLVIII (1889), pp. 406-409.

Aslanapa, Oktay: Türk Sanatı, İstanbul: Remzi Kitabevi 1984.

Ayverdi, Ekrem Hakkı: "Yugoslavyada Türk Abideleri ve Vakıfları", Vakıflar Dergisi, 3 (1957), pp. 1-73.

Balázs, Sudár: Dzsámik és mecsetek a hódolt Magyarországon. Magyar Történelmi Emlékek. Adattárak, Budapest: MTA BTK Történettudományi Intézet 2014.

Çalışkan, Özer: 16. Yüzyıl Osmanlı Saray Işlemeleri, İstanbul: İSAR 2004.

Ecthelion Bt.: Jelentés a 2015. december 1-3. között Szigetvár-Zsibót területén végzett talajradaros felmérésröl, Pécs: 2015.

Emecen, Feridun: “Gondolatok Törvényhozó Nagy Szülejmán szultán „elveszett” türbéjéről/ Kanuni Sultan Süleyman'in "Kayıp” Türbesi Üzerine Notlar," Szülejmán szultán em- 
lékezete Szigetváron/Kanuni Sultan Süleymanin Sigetvar'daki hattrası, ed. Norbert Pap [= Mediterrán és Balkán Fórum, VIII (2014)], pp. 129-135.

Evliyâ Çelebi b. Derviş Mehemmed Zıllīi: Evliyâ Çelebi Seyahatnâmesi: Topkapı Sarayı Kütüphanesi Bağdat 308 Numaralı Yazmanın Transkripsiyonu-Dizini, vol. VII, eds. Yücel Dağlı, Seyit Ali Kahraman, Robert Dankoff, İstanbul: Yapı Kredi Yayınları, 2003.

Eyice, Semavi: "Bursa'da Osman ve Orhan Gazi Türbeleri," Vakıflar Dergisi, 5 (1962), pp. $131-47$.

Gárdonyi, Máté: “A passaui „törökverő” Mariahilf-kép Szulejmán szultán szigetvári sīrja felett," Miscellanea Ecclesiae Strigoniensis, II (2004), pp. 41-49.

Győző, Gerő: Török épitészeti emlékek Magyarországon, Budapest: Corvina kiadó, 1976.

Győző, Gerő: “Az oszmán-török épītészet Magyarországon (Dzsámik, türbék, fürdők)," Müvészettörténeti Füzetek, 12 (1980).

Goodwin, Godfrey: A History of Ottoman Architecture, London: Thames \& Hudson Ltd., [1971] 2003.

Gőzsy, Zoltán: Baranya és tolna vármegye plébániáinak összeiriása 1753-1757, Pécs: Seria Historicae Dioecesis Quinqueecclesiensis XIV., 2016.

Gyenizse, Péter and Zita Bognár: "Szigetvár és környéke 16-17. századi tájrekonstrukciója katográfiai és geoinformatikai módszerekkel/Sigetvar ve Çevresinin Haritacıllk ve Jeoenformasyon Yöntemleriyle 16-17. Yüzyll Peyzaj Rekonstrüksiyonu," Szülejmán szultán emlékezete Szigetváron/Kanuni Sultan Süleymanin Sigetvar'daki hattrası, ed. Norbert Pap [= Mediterrán és Balkán Fórum, VIII (2014)], pp. 73-90.

Hancz, Erika: "Nagy Szülejmán Szultán Szigetvár környéki sátorhelye, halála és sīremléke az oszmán īrott forrásokban/Osmanlı Kaynaklarına Göre Kanuni Sultan Süleyman'ın Sigetvar'daki Otağ Yeri, Ölümü ve Türbesi," Szülejmán szultán emlékezete Szigetváron/Kanuni Sultan Süleymanin Sigetvar'daki hattrast, ed. Norbert Pap [= Mediterrán és Balkán Fórum, VIII (2014)], pp.55-71.

Hancz, Erika: Szigetvár külterület, Kápolna melletti dülö, kutatóárkos régészeti feltárása, ásatási jelentés, Pécs: Pécsi Tudományegyetem, 2013/2015.

Hancz, Erika, Fatih Elçil: "Excavations and Field Research in Sigetvar in 2009-2011, Focusing on Ottoman-Turkish Remains", International Review of Turkish Studies, II/4 (2012), pp. 74-96.

Hegyi, Klára: A török hódoltság várai és várkatonasága, I-III, Budapest: MTA Történettudományi Intézete 2007.

İbrahimgil, Mehmet Z., Neval Konuk: Kosova'da Osmanlı Mimari Eserleri, vol. I, Ankara: Türk Tarih Kurumu 2006. 
Kia, Mehrdad: Daily Life in the Ottoman Empire, Santa Barbara: The Greenwood Press Daily Life Through History Series 2011.

Kitanics, Máté: “Szigetvár-Turbék: A szultán temetkezési helye a 17-18. századi magyar, német és latin források tükrében/Sigetvar-Turbék: 17-18. Yüzyllarına Ait Macarca, Almanca ve Latince Kaynaklar Temelinde Kanuni Sultan Süleyman'ın Mezarının Oluşturulduğu Bölge," Szülejmán szultán emlékezete Szigetváron/Kanuni Sultan Süleyman'in Sigetvar'daki hatırası, ed. Norbert Pap [= Mediterrán és Balkán Fórum, VIII (2014b)], pp. 91-109.

Molnár, Imre: Budina Sámuel históriája, magyarul és latinul Szigetvár 1566. évi ostromáról, Szigetvár: A Szigetvári Várbaráti Kör Kiadványai 61978.

Molnár, Imre: Molnár Imre válogatott irásai, Szigetvár: Szigetvári Várbaráti Kör 2009.

Molnár, József: “Szulejmán szultán sīremléke Turbéken,” Müvészettörténeti Értesìtō, XIV/1 (1965), pp. 64-66.

Németh, Béla: Szigetvár története, Pécs: Pécsi Irodalmi és Könyvnyomdai Részvénytársaság 1903.

Önkal, Hakkı: "'Maqam' Tombs and the Tomb of Süleyman the Magnificent in Szigetvar", Thirteenth International Congress of Turkish Art (2009), pp. 545-549.

Pál, Hal: Szigetvár 1688 és 1689-ben. Szigetvár török uralom alól való felszabadulásának 250. évfordulója alkalmából, Szigetvár: 1939.

Pap, Norbert: “A szigetvári Szülejmán-kutatás kezdetei, a 2013-as év fontosabb eredményei / Sigetvar'da Kanuni Sultan Süleyman Hakkında Yapılan Arastırmaların Ana Noktaları ve 2013 Yılı Sonuçları," Szülejmán szultán emlékezete Szigetváron/Kanuni Sultan Süleymanin Sigetvar'daki hatırası, ed. Norbert Pap [= Mediterrán és Balkán Fórum, VIII (2014)], pp. 23-36.

Pap, Norbert ed.: Szülejmán szultán emlékezete Szigetváron/Kanuni Sultan Süleymanin Sigetvar'daki hatırası [= Mediterrán és Balkán Fórum, VIII (2014)].

Pap, Norbert and others: "Finding the tomb of Suleiman the Magnificent in Szigetvár, Hungary: historical, geophysical and archeological investigations," Die Erde, CXLVI/4 (2015), pp. 289-303.

Pesti, János: Baranya megye földrajzi nevei I., Pécs: Baranya monográfia sorozat. Baranya Megyei Levéltár 1982, pp. 452-473.

Ruzsás, Lajos and Endre Angyal: “Cserenkó és Budina,” Századok, CV (1971), pp. 57-69.

Szabó, Géza: “Leletanyag intenzitásvizsgálatok a Szülejmán szultán szigetvári türbéjéhez tartozó kaszaba helyének meghatározásához,” Archeometriai Mühely, XII/2 (2015), pp. 89-102.

Szabó, Géza and others: "Szülejmán szultán szigetvári türbéje körül talált izniki fajansztöredékek összehasonlītó vizsgálata és az ahhoz kapcsolódó terepi kutatások eredményei," Gesta, XIII (2014), pp. 59-78. 
Szabó, Géza and others: “A Szülejmán-kori harcászat és haditechnika a szigetvári ágyú és lövedékek archeometallurgiai vizsgálatának tükrében,” Gesta, XII (2013), pp. 83115.

Şenyurt, Oya: "Kosova'da Murad Hüdavendigar Türbesi ve Ek Yapıları," METU JFA, XXIX/2 (2012), pp. 285-311.

Takáts, Sándor: ”Vezīr Szokolli Musztafa Basa," Budapesti Szemle, 162 (460) (1915), pp. 41-65.

Takáts, Sándor: "Nagy Szolimán császár sīrja," Rajzok a török világból, IV (1927), pp. 123-132.

Tamás, K. Pintér, Sudár Balázs: Oszmán-török épitészet Magyarországon, Budapest: Album, 2014.

Tarım Ertuğ, Zeynep: XVI. yüzyıl Osmanlı devletinde cülûs ve cenaze törenleri, Ankara: Kültür Bakanlığı, 1999.

Tekindağ, M. C. Şehabeddin: "Fâtih'in Ölümü Meselesi," Tarih Dergisi, XVI/21 (1970), pp. 95-108.

Teksarı, Serhat: İstanbul Türbeleri, İstanbul: Gül Neşriyat, 2005.

Tóth, Tamás and Zoltán Hámori: Research in Szigetvár localising the former Ottoman settlement of Turbek, the place where the inner organs of Suleiman the Magnificient were buried, Budapest: Report of geophysical examinations in Turbék made by Geomega LTD 2014.

Turan, Osman: Selçuklular zamanında Türkiye, İstanbul: Turan Neşriyat Yurdu 1971.

Uzunçarşıll, İsmail Hakkı: "Fâtih Sultan Mehmed'in Ölümü”, Belleten, XXXIV/134 (1970), pp. 231-234.

Valéria, Kováts: “Szigetvár-Turbék szőlőhegy”, Régészeti füzetek I., No. 26 (1973), p. 113.

Valéria, Kováts: Turbék ásatási jelentés, Pécs: Janus Pannonius Múzeum Régészeti Adattár 1971, No. 1638.83.

Vass, Előd: “Szigetvár város és a szigetvári szandzsák jelentősége az Oszmán-Török Birodalomban 1565-1689," Tanulmányok a török hódoltság és a felszabaditó háborúk történetéböl (1993), pp. 193-217.

Vatin, Nicolas: "Un türbe sans maître. Note sur la fondation de la destination du türbe de Soliman-le-Magnifique à Szigetvár”, Turcica, XXXVII (2005), pp. 9-42.

Wagner, Johann Christoph: Wagners Christlich- und Türckischer Städt- und GeschichtSpiegel [...] Anhang/Oder Continuation Zu dem Christlich-und Türckischen Staedt [...], Augsburg: Gedruckt und Verlegt bey Jakob Koppmayer 1700.

Zoltán, Gőzsy: Szigetvár története a 18. században, Szigetvár: Szigetvári Kultúr- és Zöld Zóna Egyesület és a Szigetvári Várbaráti Kör, 2012. 